\title{
The Case of Procalcitonin for Lower Respiratory Tract Infections
}

\author{
Meropi Karakioulaki ${ }^{1}, \mathrm{BSc}, \mathrm{MSc}$ and Daiana Stolz ${ }^{2}, \mathrm{MD}, \mathrm{MPH}, \mathrm{FERS}, \mathrm{FCCP}$
}

${ }^{1}$ School of Medicine, Aristotle University of Thessaloniki, Greece; ${ }^{2}$ Clinic of Pulmonary Medicine and Respiratory Cell Research, University Hospital, Basel, Switzerland

\section{ABSTRACT}

Lower respiratory tract infections (LRTIs) contribute significantly to the morbidity and mortality among all age groups. Antibiotics can effectively treat LRTIs due to bacterial infection. Unfortunately, they are commonly prescribed even when the cause of the infection is non-bacterial, leading to an increase in antimicrobial resistance, mortality and health costs. This review aims to highlight the importance of procalcitonin (PCT) for the diagnosis of bacterial LRTIs. We conclude that PCT serum levels can help clinicians establish the need for antibiotics and individualise the duration of treatment in LRTIs. In addition, serum PCT provide prognostic information about the severity of the disease. However, PCT serum levels cannot inform decisions on a stand-alone fashion and should not be expected to substitute a thorough history and physical examination. (BRN Rev. 2019;5(4):277-93) Corresponding author: Daiana Stolz,daiana.stolz@usb.ch

Key words: Biomarker. Lower respiratory tract infections. Procalcitonin. 


\section{INTRODUCTION}

Lower respiratory tract infections (LRTIs) are a significant cause of morbidity and mortality among all age groups. The term LRTIs encompasses many entities including acute bronchitis, pneumonia and acute exacerbations of asthma and chronic obstructive pulmonary disease (COPD) $)^{1,2}$. The most common symptoms of LRTIs include shortness of breath, weakness, fever, coughing and fatigue $^{3}$.

Bronchitis is the inflammation of bronchial tubes and it can be acute or chronic ${ }^{4}$. Acute bronchitis is attributed to acute bacterial infection of the larger airways, but is most often caused by viral infection and hence antibiotic therapy is not indicated in immunocompetent individuals ${ }^{4}$.

Pneumonia is classified as either communityor nosocomial-acquired according to where the patient contracted the infection. Community-acquired pneumonia (CAP) is the third most common cause of death globally, the major cause of death in developed countries and it accounts for between 5\% and $12 \%$ of all cases of adult LRTIs managed by primary care physicians ${ }^{5-8}$. Nosocomial pneumonia can be divided into two groups: hospital-acquired pneumonia (HAP) and ventilator-associated pneumonia (VAP). The former, HAP, refers to an episode of pneumonia occurring more than $48 \mathrm{~h}$ after hospital admission, while VAP refers to an episode of pneumonia occurring more than $48 \mathrm{~h}$ after the onset of invasive mechanical ventilation?.

\section{IMPACT OF INCORRECT USE OF ANTIBIOTICS}

Antibiotics are an effective treatment for LRTIs of bacterial aetiology. However, they are commonly prescribed for non-bacterial LRTIs $^{10}$. The overuse of antibiotics is highly associated with an increase in antimicrobial resistance, mortality and health costs ${ }^{11}$. The World Health Organisation (WHO) recently declared antibiotic resistance to be one of the biggest threats to global health, food security and development today ${ }^{12}$. Overexposure and overuse of antibiotics also increase the risk of allergic reactions and Clostridium difficile infections ${ }^{13,14}$. The United States (US) Centers for Disease Control and Prevention (CDC) estimate at least 37,000 deaths (including deaths related to Clostridium difficile) directly related to antibiotic abuse and resistance, with an annual direct and indirect healthcare cost of 55 billion dollars ${ }^{12}$.

Evans et al. ${ }^{15}$ reported that about $75 \%$ of the patients presenting with a respiratory tract infection receive antibiotics, despite the evidence that most of those infections have viral causes. In LRTIs, however, the differentiation between bacterial and viral causes remains challenging due to the ensuing common clinical symptoms and lack of criteria for their differential diagnosis. Consequently, overuse of antibiotics is very common ${ }^{16,17}$.

Thus, an effective biomarker, which reliably contributes to the early classification of LRTIs as bacterial or non-bacterial could significantly decrease the number of unnecessary antibiotic prescriptions, hence reducing antimicrobial resistance and antibiotic-related 
adverse events. In the present review, we will consider the available data for the use of procalcitonin (PCT) as such a biomarker.

\section{THE PHYSIOLOGY OF PROCALCITONIN}

Procalcitonin is the precursor of the hormone calcitonin (CT), which is responsible for the metabolic regulation of calcium and phosphate throughout the body ${ }^{18}$. The calcitonin related polypeptide alpha (CALCA) gene, located on chromosome 11, is responsible for the production of the PCT messenger ribonucleic acid (mRNA) and the subsequent formation of PCT, a 116-amino-acid prohormone, which is then cleaved into the active 32-amino-acid hormone $\mathrm{CT}^{18}$ (Fig. 1).

Usually, PCT is produced entirely within the thyroid C cells and is converted to CT before it enters the systemic circulation ${ }^{18}$ (Fig. 1). Hence, healthy individuals typically demonstrate very low levels of serum PCT, less than $0.02 \mathrm{ng} / \mathrm{ml}$. In contrast, patients that suffer from systemic bacterial infections were shown to produce PCT via an alternative pathway, in non-thyroid tissues, like the spleen, kidneys, adipocytes, pancreas, colon, brain and lungs ${ }^{19}$ (Fig. 2A). These tissues lack the processing pathway necessary to convert PCT to CT, and therefore PCT enters the systemic circulation and PCT serum levels rise ${ }^{18}$ (Fig. 2A). Other studies demonstrate that, in healthy patients, PCT serum levels usually are below $0.05 \mathrm{mg} / \mathrm{mL}$ while in patients with sepsis (severe sepsis or septic shock) PCT levels can reach $1000 \mathrm{mg} / \mathrm{mL}^{19}$. There is evidence that levels greater than $0.25 \mathrm{ng} / \mathrm{ml}$ may indicate the presence of bacterial infection ${ }^{18}$. Serum levels decline as patients recover from bacterial infections, which is an indication for clinical improvement. Remarkably, the magnitude of PCT increase in systemic circulation reflects the intensity of the host immune response and thus provides a useful assessment of infection severity. Bacteria, lipopolysaccharide and pro-inflammatory cytokines trigger the production of PCT and, thus, PCT levels are highest in both acute bacterial infections and sepsis. By contrast, PCT levels are not elevated in most autoimmune-mediated inflammation or localised infections ${ }^{18}$. Importantly, there might be only a marginal increase in PCT levels in non-invasive lung parenchymal infections, such as bronchiectasis and cystic fibrosis as well as in tuberculosis ${ }^{18,20-23}$.

Procalcitonin is particularly sensitive to bacterial toxins, but it undergoes down-regulation in the presence of viral infections ${ }^{24}$. That is because cytokines, typically associated with bacterial infection (such as tumour necrosis factor and interleukin [IL]-6), enhance PCT release $\mathrm{e}^{24,25}$ (Fig. 2). On the other hand, the production of interferon- $\gamma$ and other interferons in virus-infected cells seems to inhibit the production of PCT (Fig. 2B). Therefore, PCT can be used as a tool to differentiate viral versus bacterial infections and to determine the need of antibiotic therapy ${ }^{18,24,25}$.

The PCT serum levels may also increase after fungal infections, although to a lesser extent than bacterial infections (ranges of $0.69-1.23 \mathrm{ng} / \mathrm{ml}$ and $4.18-12.9 \mathrm{ng} / \mathrm{ml}$ respectively $)^{26}$. Of note that PCT serum levels greater than $2 \mathrm{ng} / \mathrm{ml}$ could provide a criterion to withhold antifungal therapy in patients with clinical sepsis while waiting for other confirmatory results ${ }^{26}$. 


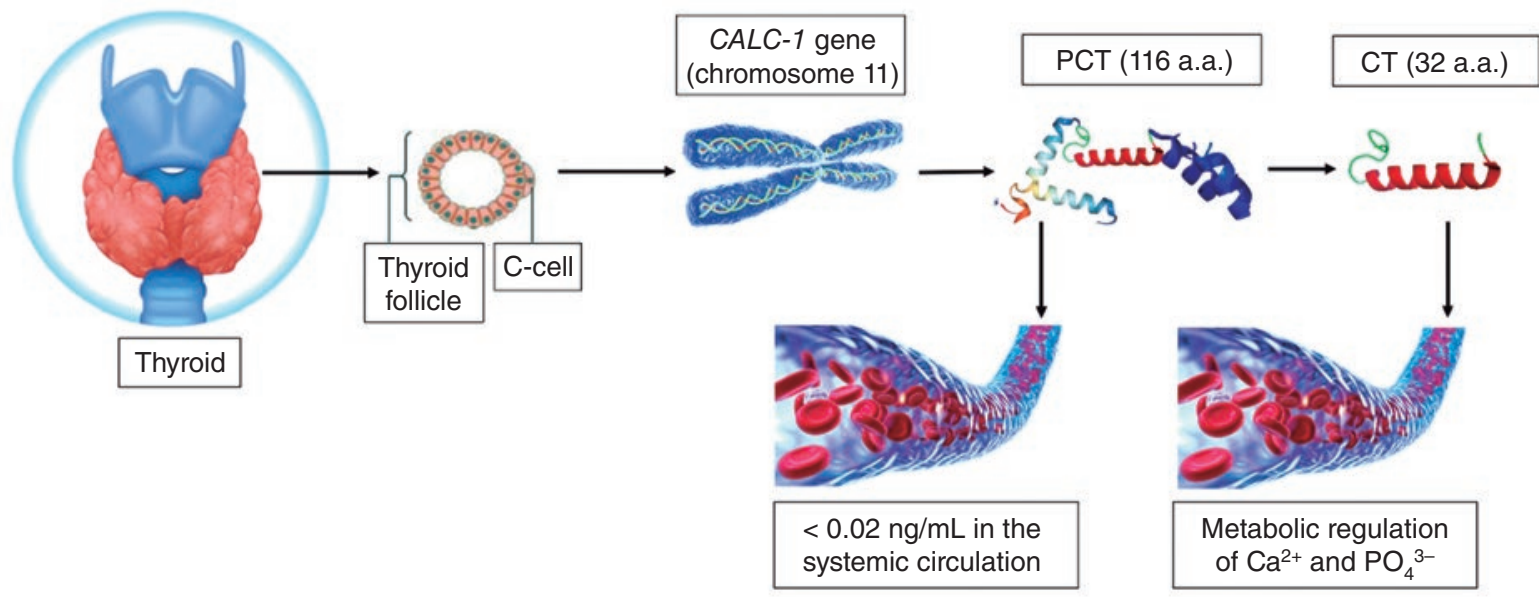

Figure 1. The physiological pathway of calcitonin (CT) takes place in the thyroid C cells. Initially the pathway leads to the production of procalcitonin (PCT), a 116 amino-acid prohormone which is then cleaved into the 32 amino-acid hormone CT, which is responsible for the metabolic regulation of calcium and phosphate. Normally, PCT is converted to CT before it enters the systemic circulation. Hence, healthy individuals typically demonstrate very low levels of serum PCT, less than $0.02 \mathrm{ng} / \mathrm{ml}$.

Molecular structures adjusted from the following databases: Ca ${ }^{2+}$ : calcium ions; CT: UniProt ID P01258 (CALC_HUMAN); PCT: theoretical structure, since the crystal structure of PCT is not yet available; $\mathrm{PO}_{4}{ }^{3-}$ : phosphate anion.

The PCT levels start to rise within 3-4 $\mathrm{h}$ of inoculation with bacteria or bacterial endotoxin and peak after $12-24 \mathrm{~h}^{18}$. On the other hand, cytokines (such as IL-6) and tumour necrosis factors (TNF) peak rapidly within 5-10 $\mathrm{h}$ and normalise within $20 \mathrm{~h}$, therefore being inadequate biomarkers to track clinical progress ${ }^{18}$.

\section{DIAGNOSTIC VALUE OF PROCALCITONIN}

The US Food and Drug Administration (FDA) approved PCT as a biomarker for sepsis in 2005. The PCT assays have recently been approved for the initial diagnosis of patients with LRTIs and antibiotic therapy guidance in all LRTIs including acute bronchitis, pneumonia, exacerbation of COPD and asthma ${ }^{27}$. The FDA guidelines allow PCT testing only in hospital laboratories so that, depending on the assay being used, the results are often available in $20 \mathrm{~min}$ to $2.5 \mathrm{~h}^{28}$. Several European countries are using various PCT assays for the decision-making in patients with COPD, bronchitis, pneumonia, sepsis or risk for sepsis ${ }^{29,30}$ (Fig. 3).

Although far from being ideal, PCT is one of the most well-studied biomarkers in RCTs including over 7000 patients suffering with all types of LRTIs, at all treatment settings. It has been proved to have a more favourable kinetic profile and to be more sensitive and specific than other biomarkers, such as IL-6, C reactive protein (CRP) and lactate ${ }^{31,32}$; it demonstrates a mean sensitivity of $94.1 \%$ and specificity of $88.4 \%$ for the diagnosis of LRTIs ${ }^{33}$ with a negative predictive value to rule out LRTIs to be 


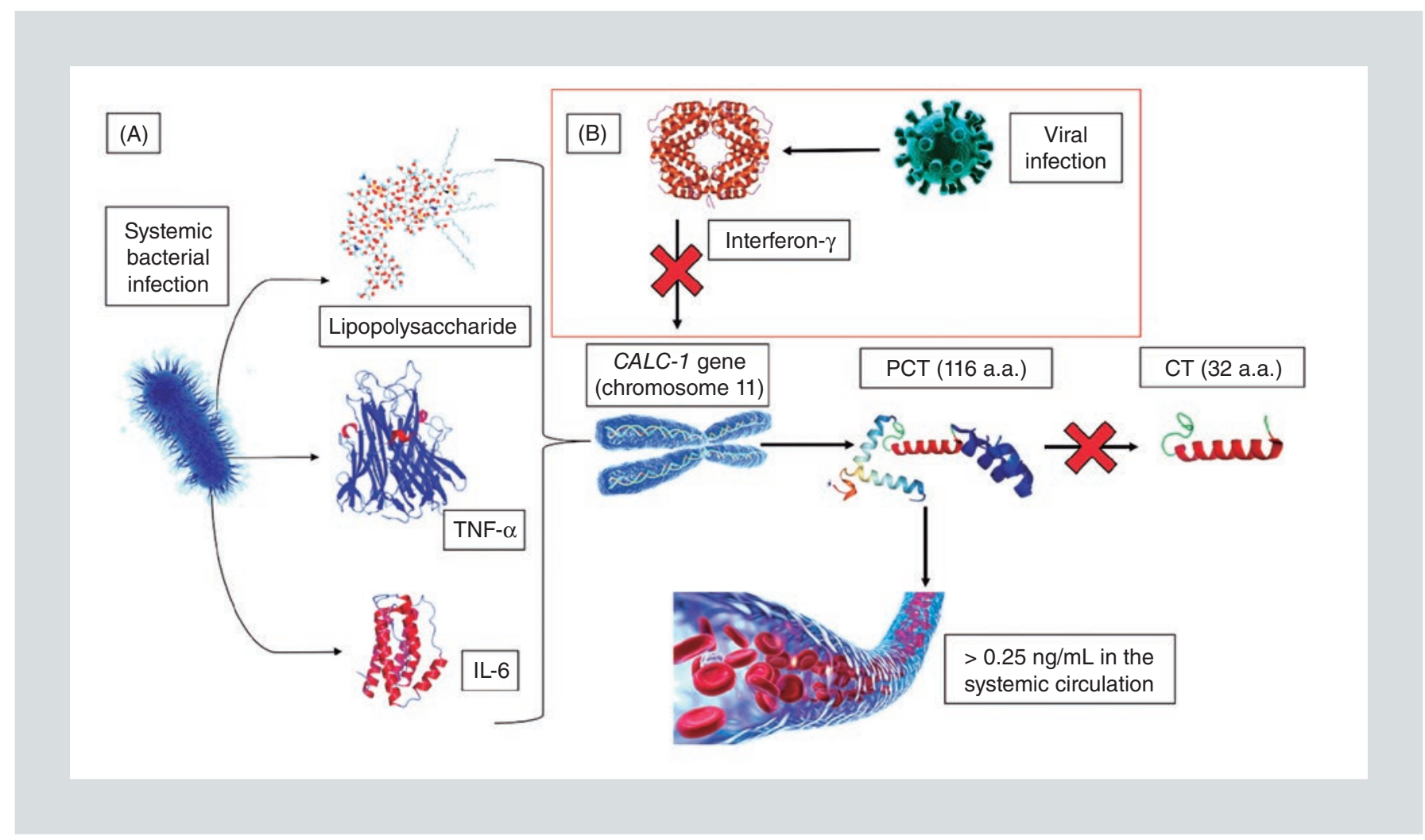

FIGURE 2. (A) The alternative pathway of procalcitonin (PCT) is activated after systemic bacterial infection and takes place in non-thyroid tissues, such as the spleen, kidneys, adipocytes, pancreas, colon, brain and lungs. This pathway is activated because cytokines, typically associated with bacterial infection, such as tumour necrosis factor-alpha (TNF $\alpha$ ), interleukin-6 (IL-6) and lipopolysacharides, enhance PCT release. As a result, more than $0.25 \mathrm{ng} / \mathrm{mL}$ of PCT can be measured in the systemic circulation. (B) The production of interferon- $\gamma$ and other interferons in virus infected cells seems to inhibit the production of PCT. Serum PCT can therefore be used as a tool to differentiate viral versus bacterial infections and to determine the need for antibiotic therapy.

Molecular structures adjusted from the following databases: CT: UniProt ID P01258 (CALC_HUMAN); IL-6: UniProt ID P05231 (IL6_ HUMAN); Interferon- $\gamma$. UniProt ID P01579 (IFNG_HUMAN); Lipopolysaccharide: PubChem CID 11970143; PCT: theoretical structure, since the crystal structure of PCT is not yet available; TNF- $\alpha$ : UniProt ID P01375 (TNFA_HUMAN).

CT: calcitonin.

$\operatorname{PCT}(\mathrm{ng} / \mathrm{ml})$

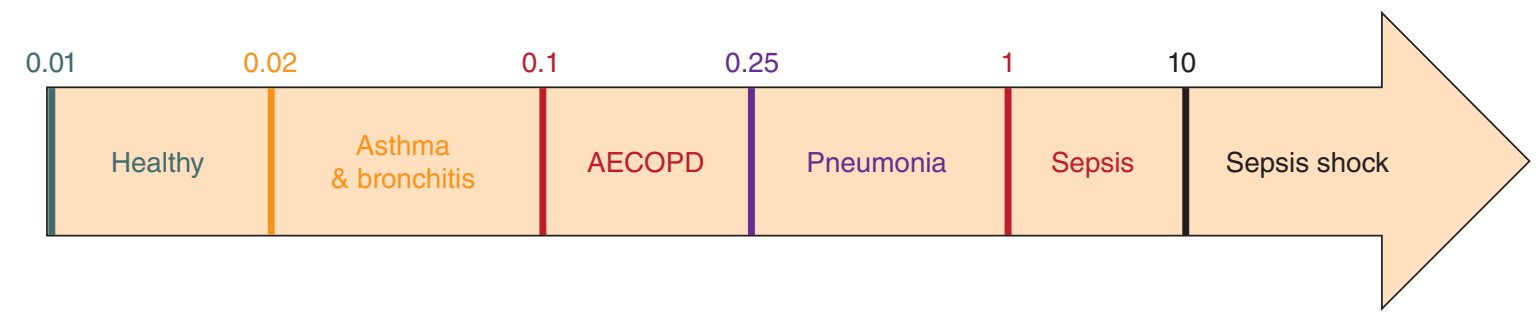

Figure 3. Serum levels of PCT (ng/ml) at various clinical scenarios $27,29,30,76$.

AECOPD: acute exacerbation of chronic obstructive pulmonary disease; PCT: procalcitonin. 
between $89-94 \% 34$. Data from various studies show a great range of $31 \%-94 \%$ for sensitivity and $71 \%-98 \%$ for specificity ${ }^{27}$. This variation in ranges is possibly due to the lack of a gold standard for the diagnosis of bacterial LRTIs, i.e. difficulties in reliably identifying the distinct bacterial pathogens in patients with LRTIs ${ }^{27}$.

Serum PCT is a biomarker that has been shown to safely guide antibiotic therapy in LRTIs ${ }^{24}$. A review of several randomised controlled trials (RCTs) in patients with COPD demonstrated that, when compared to standard therapy, PCT-guided antibiotic therapy resulted in fewer antibiotic prescriptions and shorter antibiotic durations, without an increase in adverse outcomes ${ }^{35}$.

A meta-analysis of 11 studies indicated that PCT is an effective serum biomarker in guiding antibiotic therapy in LRTIs by reducing antibiotic initiation and use compared to the standard of care, with no observed adverse effects on hospital length of stay and all-cause mortality ${ }^{12}$. These results are consistent with another meta-analysis that included 14 trials and 4221 patients and reported that PCT guidance had no impact on mortality (odds ratio [OR] $=0.94,95 \%$ confidence interval [CI]: 0.71-1.23), PCT-guided patients had lower odds of treatment failure $(\mathrm{OR}=0.82,95 \% \mathrm{CI}$ : 0.71-0.97), fewer days of exposure to antibiotics (median of 1.6 days from 4.6 days) and lower odds of antibiotic initiation $(\mathrm{OR}=0.24,95 \% \mathrm{CI}: 0.20-0.29)^{36}$. Overall antibiotic use was reduced to $60 \%{ }^{36}$.

A multicentre study on 1735 adults hospitalised with CAP, 645 of which had a viral or bacterial pathogen detected, revealed that higher PCT serum levels on day of hospital admission were strongly associated with increased probability of bacterial pathogen detection ${ }^{37}$. Patients with $10 \mathrm{ng} / \mathrm{mL}$ of PCT serum levels were 4 times more likely to have a bacterial pathogen detected than those with PCT $<0.05 \mathrm{ng} / \mathrm{mL}^{37}$. No PCT threshold, however, allowed for perfect discrimination between viral and bacterial detection, as $23 \%$ of the patients with bacterial pathogens had serum levels of PCT $<0.25 \mathrm{ng} / \mathrm{mL}$ and $12 \%$ had $\mathrm{PCT}<0.1 \mathrm{ng} / \mathrm{mL}^{37}$. However, these data suggest that serum PCT levels, which can be available to clinicians within one hour after a simple blood draw, could be useful to diagnose the bacterial aetiology of patients hospitalised with $\mathrm{CAP}^{37}$.

Results of a RCT indicated that PCT-guided therapy was non-inferior to the standard medical decision making for the use of antibiotics for LRTIs ${ }^{20}$. In this study, antibiotic prescriptions were reduced to $72 \%$ when using the PCT-guided approach, without any change in patient morbidity, treatment failure or mortality ${ }^{20}$.

Concerning appropriate PCT levels for antibiotic prescription, Watkins et al. ${ }^{27}$ recommended that PCT levels less than $0.1 \mathrm{mg} / \mathrm{mL}$ should strongly discourage antibiotic therapy, levels greater than $0.1 \mathrm{mg} / \mathrm{mL}$ but lower than $0.25 \mathrm{mg} / \mathrm{mL}$ discourage antibiotic therapy, levels greater than $0.25 \mathrm{mg} / \mathrm{mL}$ but less than $0.5 \mathrm{mg} / \mathrm{mL}$ encourage antibiotic therapy and levels greater than $0.5 \mathrm{mg} / \mathrm{mL}$ strongly encourage antibiotic therapy.

Therefore, PCT has been shown to be able to help decision-making for both initiation and cessation of antibiotic treatment in patients with LRTIs $^{36,38-40}$ and is widely recognised as an effective biomarker for bacterial infection ${ }^{36,41,42}$. In a meta-analysis of 12 studies, PCT was 
compared to CRP and the diagnostic accuracy of PCT was shown to be higher than that of CRP among patients hospitalised for suspected bacterial infections ${ }^{43}$.

Concerning HAP/VAP, PCT can be a strong predictor for risk of death and a promising biomarker for the duration of treatment ${ }^{44}$. On the other hand, it appears to be less reliable for the diagnosis of VAP, because patients with HAP/VAP have already developed systemic inflammation response syndromes, multiple organ failure, and/or previous infection, conditions that raise PCT serum levels ${ }^{45}$. Therefore, clinicians should not use PCT as the only determinant to diagnose $\mathrm{HAP} / \mathrm{VAP}^{46}$. Instead, serial measurements of PCT should always be accompanied with the clinical assessment of the patients, in order to decide on the initiation or completion of antibiotic therapy ${ }^{44,46}$. In an observational study of 45 patients who developed VAP, PCT levels at days 3 and 7 were significantly higher in non-survivors than in survivors $^{47}$. The PCT levels at day 3 were the strongest predictor of mortality, and fell significantly from day 0 to day 7 in the survivor group, while CRP levels did not ${ }^{47}$. Another study demonstrated that in patients on mechanical ventilation, daily CRP monitoring appears to be more useful than PCT for the diagnosis of $\mathrm{VAP}^{48}$.

To conclude, among patients with varying types of severity of acute respiratory tract infection, using PCT to guide decisions about antibiotics is associated with lower rates ofantibiotic exposure, antibiotic-related adverse effects and mortality, but PCT is not a useful biomarker for the diagnosis of VAP/HAP and in those cases daily CRP monitoring should be implemented (Table 1). The diagnostic value of PCT in different kinds of LRTIs is depicted in table 1.

\section{PROGNOSTIC VALUE OF PROCALCITONIN}

Procalcitinonin levels were also shown to correlate with the severity and extent of microbial invasion. Higher PCT levels are usually indicative of a poorer prognosis ${ }^{49,50}$. A study on 427 patients in intensive care units (ICU) indicated an association between increased mortality and PCT serum levels greater than $1 \mathrm{ng} / \mathrm{ml}^{50}$. In another study of 243 adult patients presenting to emergency rooms, PCT levels of $2 \mathrm{ng} / \mathrm{ml}$ or greater were significantly associated with critical illness (OR 2.51, 95\% CI 1.25-5.04) $)^{51}$.

A meta-analysis reported a significant reduction in 30-day mortality in patients with acute respiratory infections receiving PCT-guided therapy, compared to those receiving the standard care $(9 \%$ versus $10 \%$, adjusted OR $0.83,95 \%$ CI $0.70-0.99)^{42}$. The prognostic value of PCT in different kinds of LRTIs is depicted in table 1 . Another analysis of patients primarily treated for pneumonia in a rural community hospital also noted a decrease in the rate of mortality after PCT-guided treatment was implemented $(2.9 \%$ after PCT versus $7.6 \%$ before PCT, $\mathrm{p}<0.001)^{52}$.

A multicentre RCT additionally indicated that there is a reduction in mean hospital length of stay from 7.1 days in the control group to 4.8 days in the PCT-guided group in the subgroup of patients with COPD $(p=0.009)^{53}$ (Table 1). 
TABLE 1. Summary of the diagnostic and prognostic values of procalcitonin (PCT), as well as of the value of PCT as a determinant for antibiotic therapy initiation and duration in different clinical set-ups

\begin{tabular}{|c|c|c|c|}
\hline Clinical scenarios & Diagnostic value of PCT & Prognostic value of PCT & Antibiotic stewardship \\
\hline \multirow[t]{3}{*}{$\begin{array}{l}\text { Acute bronchitis } \\
\text { in the healthy } \\
\text { population }\end{array}$} & & $\begin{array}{l}\text { Treatment failure, length of hospital } \\
\text { stay, antibiotic-related side effects } \\
\rightarrow \text { no significant difference between } \\
\text { control and PCT group }{ }^{42}\end{array}$ & $\begin{array}{l}\text { Initiation of antibiotics } \rightarrow \text { significantly } \\
\text { lower in PCT group compared } \\
\text { to control }\end{array}$ \\
\hline & & & $\begin{array}{l}\text { No significant difference in duration } \\
\text { of antibiotics and total exposure of } \\
\text { antibiotics }^{42}\end{array}$ \\
\hline & & & $\begin{array}{l}\text { PCT-guided antibiotic stewardship } \\
\text { reduces overall antibiotic exposure } \\
\text { and associated side effects }{ }^{76}\end{array}$ \\
\hline \multirow[t]{5}{*}{$\begin{array}{l}\text { Exacerbation } \\
\text { of COPD }\end{array}$} & & $\begin{array}{l}\text { Mean hospital length of stay in the } \\
\text { standard care group }=7.1 \text { days }{ }^{53}\end{array}$ & $\begin{array}{l}\text { Initiation of antibiotics, duration } \\
\text { of antibiotics } \rightarrow \text { significantly lower } \\
\text { in PCT group compared to control }{ }^{42}\end{array}$ \\
\hline & & $\begin{array}{l}\text { Mean hospital length of stay in the } \\
\text { PCT- guided group }=4.8 \text { days }^{53}\end{array}$ & $\begin{array}{l}\text { No significant difference in total } \\
\text { exposure of antibiotics between PCT } \\
\text { group and control }{ }^{42}\end{array}$ \\
\hline & & $\begin{array}{l}30 \text { day mortality, treatment failure, length } \\
\text { of hospital stay, antibiotic-related side } \\
\text { effects } \rightarrow \text { no significant difference } \\
\text { between control and PCT group }{ }^{42}\end{array}$ & $\begin{array}{l}47.1 \% \text { relative reduction of antibiotic } \\
\text { exposure over } 6 \text { months in PCT } \\
\text { group }^{1}\end{array}$ \\
\hline & & & $\begin{array}{l}\text { PCT-guided antibiotic therapy } \\
\rightarrow \text { fewer antibiotic prescriptions } \\
\text { and shorter antibiotic durations, } \\
\text { no increase in adverse outcomes }{ }^{35}\end{array}$ \\
\hline & & & $\begin{array}{l}\text { Antibiotic protocol guided by serum } \\
\text { levels of PCT failed to reduce in-ICU } \\
\text { and in-hospital antibiotic exposure } \\
\text { compared to the standard antibiotic } \\
\text { therapy }\end{array}$ \\
\hline $\begin{array}{l}\text { Exacerbation } \\
\text { of asthma }\end{array}$ & & & $\begin{array}{l}\text { PCT monitoring results in a reduction } \\
\text { of antibiotic therapy duration } \\
\text { in the range of } 0-8 \text { days, with } \\
\text { no impact on infection relapses }{ }^{64}\end{array}$ \\
\hline \multirow[t]{2}{*}{$\begin{array}{l}\text { Mild CAP usually } \\
\text { managed by GPs }\end{array}$} & $\begin{array}{l}\text { Influenza season: severe forms } \\
\text { of H1N1 show elevated levels of PCT } \\
\text { in the absence of proven bacterial } \\
\text { co-infection } 74\end{array}$ & $\begin{array}{l}\text { PCT- guided therapy, compared } \\
\text { to standard care } \rightarrow \text { reduction } \\
\text { of } 30 \text {-day mortality }{ }^{42}\end{array}$ & \\
\hline & $\begin{array}{l}\text { Patients } \geq 3 \text { days since onset of } \\
\text { symptoms } \rightarrow \text { lower levels serum of } \\
\text { PCT; PCT should be used as a } \\
\text { biomarker for antibiotic initiation } \\
\text { only within the first } 48 \text { hours since } \\
\text { onset of symptoms }{ }^{69}\end{array}$ & $\begin{array}{l}\text { Decrease in mortality rate: } 2.9 \% \text { after } \\
\text { PCT-guided treatment versus } 7.6 \% \\
\text { before PCT-guided treatment, } \\
\mathrm{p}<0.001^{52}\end{array}$ & \\
\hline \multirow[t]{2}{*}{$\begin{array}{l}\text { Hospital admitted } \\
\text { severe CAP } \\
\text { or sepsis }\end{array}$} & $\begin{array}{l}\text { PCT }=10 \mathrm{ng} / \mathrm{mL} \rightarrow 4 \text { times increased } \\
\text { likelihood for a bacterial infection } \\
\text { than } \mathrm{PCT}<0.05 \mathrm{ng} / \mathrm{mL}^{37}\end{array}$ & $\begin{array}{l}\text { Higher PCT levels indicate a poorer } \\
\text { prognosis } \\
49,50\end{array}$ & $\begin{array}{l}\text { Initiation of antibiotics, duration } \\
\text { of antibiotics, total exposure of } \\
\text { antibiotics } \rightarrow \text { significantly lower } \\
\text { in PCT group compared to control }\end{array}$ \\
\hline & $\begin{array}{l}\text { Diagnostic accuracy of PCT > diag- } \\
\text { nostic accuracy of CRP }\end{array}$ & $\begin{array}{l}\text { PCT } \geq 2 \mathrm{ng} / \mathrm{ml} \text { associated with critical } \\
\text { illness }^{51}\end{array}$ & $\begin{array}{l}55.8 \% \text { relative reduction of antibiotic } \\
\text { exposure in the PCT group }\end{array}$ \\
\hline
\end{tabular}


TABLE 1. (Continuation)

\begin{tabular}{|c|c|c|c|}
\hline Clinical scenarios & Diagnostic value of PCT & Prognostic value of PCT & Antibiotic stewardship \\
\hline \multirow[t]{2}{*}{$\begin{array}{l}\text { Hospital admitted } \\
\text { severe CAP } \\
\text { or sepsis }\end{array}$} & $\begin{array}{l}\text { Bacterial and viral coinfections: } \\
\text { no withholding of antibiotic therapy } \\
\text { even with low serum levels of PCT } \\
\text { and a positive viral PCR assay }\end{array}$ & $\begin{array}{l}\text { 30-day mortality, treatment failure, } \\
\text { length of ICU and hospital stay, } \\
\text { antibiotic-related side effects } \rightarrow \text { no } \\
\text { significant difference between } \\
\text { control and PCT group }{ }^{72}\end{array}$ & $\begin{array}{l}36.8 \% \text { relative reduction of antibiotic } \\
\text { exposure in sepsis in the } \mathrm{ICU}^{99}\end{array}$ \\
\hline & & & $\begin{array}{l}23 \% \text { relative reduction of antibiotic } \\
\text { exposure in sepsis in different } \\
\text { French ICUs }{ }^{57}\end{array}$ \\
\hline \multirow[t]{2}{*}{ VAP/HAP } & $\begin{array}{l}\text { PCT is not a useful biomarker for the } \\
\text { diagnosis of VAP/HAP, instead daily } \\
\text { CRP monitoring should be imple- } \\
\text { mented } 44-48\end{array}$ & PCT $>1 \mathrm{ng} / \mathrm{ml} \rightarrow$ increased mortality ${ }^{50}$ & $\begin{array}{l}\text { No significant difference in duration } \\
\text { of antibiotics and total exposure of } \\
\text { antibiotics }^{42}\end{array}$ \\
\hline & & $\begin{array}{l}\text { 30-day mortality, treatment failure, } \\
\text { length of ICU and hospital stay } \rightarrow \text { no } \\
\text { significant difference between } \\
\text { control and PCT group }{ }^{42}\end{array}$ & $\begin{array}{l}27 \% \text { relative reduction of antibiotic } \\
\text { exposure in VAP68 }\end{array}$ \\
\hline \multirow[t]{4}{*}{ Non-specified LRTIs } & $\begin{array}{l}\text { Mean sensitivity }=94.1 \% \\
\text { Mean specificity }=88.4 \% \\
\text { For LRTIs diagnosis }\end{array}$ & $\begin{array}{l}\text { Negative predictive value for ruling } \\
\text { out LRTIs }=89-94 \%^{34}\end{array}$ & $\begin{array}{l}55.1 \% \text { relative reduction of antibiotic } \\
\text { prescription in the PCT group }{ }^{98}\end{array}$ \\
\hline & & $\begin{array}{l}\text { Higher PCT levels are usually } \\
\text { indicative of a poorer prognosis } \\
49-50\end{array}$ & $\begin{array}{l}77.9 \% \text { relative reduction of antibiotic } \\
\text { exposure }\end{array}$ \\
\hline & & & $\begin{array}{r}34.5 \% \text { relative reduction of antibiotic } \\
\text { exposure in a multicentre setting }\end{array}$ \\
\hline & & & $\begin{array}{l}25 \% \text { relative reduction of antibiotic } \\
\text { exposure in Denmark }{ }^{53}\end{array}$ \\
\hline
\end{tabular}

CAP: community-acquired pneumonia; COPD: chronic obstructive pulmonary disease; CRP: c-reactive protein; GP: general practitioner; HAP: hospital-acquired pneumonia; ICU: intensive care unit; LRTIs: lower respiratory tract infections; PCR: polymerase chain reaction; VAP: ventilation-associated pneumonia.

\section{PROCALCITONIN AS A DETERMINANT FOR ANTIBIOTIC THERAPY INITIATION AND DURATION}

Even though the use of PCT in guiding antibiotic initiation may be disputed, it is successfully assessed as part of antibiotic discontinuation protocols ${ }^{32}$. Zhang et al. ${ }^{54}(2015)$ reviewed 43 antibiotic stewardship programs (ASPs) related studies, in eight of which PCT-guided antibiotic protocols were used ${ }^{54}$. Although PCT was not proven helpful in antimicrobial initiation decision-making, it was very beneficial when used to decrease antibiotic duration and prescription in critically ill patients without increasing their mortality ${ }^{54}$. Albrich et al. ${ }^{55}$ and Brechot et al. ${ }^{56}$ also report that measurements of PCT in ICU patients are not effective to withhold the initiation of antibiotics when there is a high clinical probability of sepsis, but the use of PCT for the discontinuation of the antibiotic therapy could be implemented in clinical practice to reduce antibiotic exposure.

Another study involving 1575 patients randomly assigned to either PCT-guided or standard-of-care antibiotic discontinuation group showed that in the PCT-guided group median duration of treatment was 5 days, while in the control group it was 7 days $(p<0.0001)^{22}$. PCT 
levels less than $0.5 \mu \mathrm{g} / 1$ or a decrease of PCT levels by at least $80 \%$ of their maximum value indicated that antibiotic therapy should be discontinued ${ }^{22}$. It has also been reported that a reduction in the duration of treatment was also associated with a significant decrease in mortality ${ }^{57}$.

Procalcitonin levels should always be measured together with clinical assessments and other laboratory parameters, as PCT levels alone cannot guide antimicrobial therapy decisions $^{58}$. A PCT level lower than $0.25 \mathrm{ng} / \mathrm{ml}$ and a decrease in PCT level of $80 \%$ or more from peak levels warrant antibiotic therapy discontinuation for patients with LRTIs ${ }^{59}$. If the initial PCT level is below the threshold for antibiotic discontinuation, a repeat measurement is recommended within 6-24 h in order to account for patients with a delayed PCT peak $^{36,57,60,61}$.

A number of RCTs demonstrate that PCT monitoring results in a reduction of antibiotic therapy duration in the range of 0-8 days, with no impact on infection relapses, when compared with the standard care (no PCT monitoring) $)^{19,21,42,54,53,62-68}$.

Another very important factor that should not be omitted is the time elapsed since the first onset of symptoms of CAP, as it influences the systemic inflammatory profile of the patient ${ }^{69}$. Patients with three or more days since onset of symptoms tend to show lower levels serum of PCT, indicating that PCT should be used as a biomarker for antibiotic initiation only within the first $48 \mathrm{~h}$ since onset of symptoms ${ }^{69}$. In fact, none of the CAP studies performed so far have considered the very important variable of the time elapsed since the onset of symptoms. The latter should be considered every time when the initial diagnosis is being made, to estimate properly the inflammatory response of the patient.

Serum PCT levels, however, can be normal or low in a varying proportion of documented

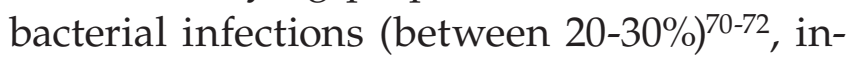
dicating that a low serum level of PCT cannot be used as the basis for deciding whether to treat a patient hospitalised for pneumonia with antibiotics ${ }^{72}$. A significant proportion of the patients with LRTIs are co-infected with bacteria and viruses and tend to have low PCT levels ${ }^{72}$. That is to say that even with low PCT serum levels and a positive viral polymerase chain reaction (PCR) assay, clinicians are not justified withholding antibiotic therapy in patients hospitalised for $\mathrm{CAP}^{72}$.

During the influenza season, PCT can be a reasonably accurate biomarker for the detection of bacterial pneumonia, particularly in patients with CAP without immune-compromising disorders ${ }^{73}$. However, it might not be sufficient as a stand-alone marker for withholding antibiotic treatment ${ }^{73}$. Indeed, some severe forms of H1N1 with respiratory failure show elevated PCT levels in the absence of proven bacterial co-infection, and these elevated PCT levels are related to the severity of the disease ${ }^{74}$.

In a multicentre, randomised trial in France with patients admitted to the intensive care unit (ICU) due to severe acute exacerbations of COPD, the antibiotic protocol guided by PCT serum levels failed to reduce in-ICU and in-hospital antibiotic exposure compared to the standard antibiotic therapy ${ }^{75}$. 
An international experts consensus group on optimizing PCT clinical use agreed that PCT-guided antibiotic stewardship supports individual decisions on initiation and duration of antibiotic treatment in patients with acute respiratory infections and sepsis and therefore is reducing overall antibiotic exposure and associated side effects ${ }^{76}$. The group re-established the PCT algorithms by incorporating the severity of illness and the probability of bacterial infection, and by reducing the fixed cut-offs to $0.25 \mu \mathrm{g} / \mathrm{L}$ for mild-moderate disease and to $0.5 \mu \mathrm{g} / \mathrm{L}$ for severe disease ${ }^{76}$. They concluded that in order to improve the diagnostic and therapeutic management of patients with a suspected bacterial infection, clinicians need to combine clinical patient assessment with PCT levels in a context of continuous education and regular feedback ${ }^{76}$.

Finally, it should be noted that in cases in which the clinical presentation remains equivocal regarding the presence of infection, a single determination of PCT serum levels at admission should not be the only indicator for initiation of antibiotic treatment; a second determination of PCT serum levels after $24 \mathrm{~h}$ is mandatory, as peak levels of PCT occur at 24 to $48 \mathrm{~h}$ after sepsis ${ }^{77}$.

To conclude, PCT appears to be an appropriate biomarker for patients with sepsis and PCT levels can be used to support discontinuation of empirical antibiotics in patients who initially appeared to have sepsis, but subsequently have limited clinical evidence of infection $^{78}$ (Table 2). More studies to consider the very important variable of the time period since onset of CAP symptoms should be warranted in the future. The value of PCT as a determinant for antibiotic therapy initiation and duration in different kinds of LRTIs is depicted in table 1.

\section{CONSIDERATIONS FOR SPECIFIC POPULATIONS}

There are a number of comorbid conditions that were shown to elevate PCT in the absence of bacterial infection. Those conditions include massive stress due to severe trauma or surgery (especially major cardiothoracic or abdominal surgery), major burns, medullary thyroid carcinoma, prolonged or severe cardiogenic shock, small cell lung cancer, treatment with OKT3 antibodies, resuscitated cardiac arrest and anti-thymocyte globulin which stimulates the release of pro-inflammatory cytokines ${ }^{79,80}$. Procalcitonin elevations may also occur to patients with other acute or chronic conditions, including pancreatitis, rhabdomyolysis, severe hepatic dysfunction and severe renal dysfunction $^{77}$, as end-stage renal disease and chronic kidney disease represent syndromes involving inflammatory responses ${ }^{60}$. Patients with underlying autoimmune diseases, such as Kawasaki disease, Goodpasture syndrome, and autoimmune hepatitis may also present with elevated $\mathrm{PCT}^{77}$. Mild increase in PCT levels can also occur in patients with rheumatoid arthritis, inflammatory bowel disease, and systemic lupus erythematosus ${ }^{77}$. Additionally, patients with underlying malignancy, submitted to transplants and those receiving certain chemotherapeutic medications (such as monoclonal antibodies) may have increased PCT serum levels ${ }^{81}$. Last but not least, neonates demonstrate elevations in PCT levels during the first three days of life ${ }^{18}$. 
TABLE 2. Summary of cases where procalcitonin (PCT) may or may not be used as a biomarker in order to guide antibiotic therapy initiation and duration

\begin{tabular}{|c|c|}
\hline PCT as a determinant for antibiotic therapy initiation and duration & Reference \\
\hline $\begin{array}{l}\text { PCT-guided therapy resulted in fewer antibiotic prescriptions and shorter antibiotic therapy durations - no increase in } \\
\text { adverse outcomes }\end{array}$ & [37] \\
\hline $\begin{array}{l}\text { PCT-guided therapy reduced antibiotic initiation and use, compared to standard of care- no observed adverse effects on } \\
\text { hospital length of stay and all-cause mortality }\end{array}$ & [12] \\
\hline $\begin{array}{l}\text { PCT-guided patients with lower odds of treatment failure, fewer days of exposure to antibiotics and lower odds of } \\
\text { antibiotic initiation - overall antibiotic use reduced to } 60 \%\end{array}$ & [36] \\
\hline PCT-guided approach: antibiotic prescriptions reduced to $72 \%$ - no change in patient morbidity, treatment failure or mortality & [20] \\
\hline $\begin{array}{l}\text { PCT }<0.1 \mathrm{mg} / \mathrm{mL} \rightarrow \text { strongly discourage antibiotic therapy } \\
0.1 \mathrm{mg} / \mathrm{mL}<\mathrm{PCT}<0.25 \mathrm{mg} / \mathrm{mL} \rightarrow \text { discourage antibiotic therapy } \\
0.25 \mathrm{mg} / \mathrm{mL}<\mathrm{PCT}<0.5 \mathrm{mg} / \mathrm{mL} \rightarrow \text { encourage antibiotic therapy } \\
0.5 \mathrm{mg} / \mathrm{mL}<\mathrm{PCT} \rightarrow \text { strongly encourage antibiotic therapy }\end{array}$ & [27] \\
\hline $\begin{array}{l}\text { PCT-guided group } \rightarrow \text { median duration of treatment }=5 \text { days } \\
\text { control group } \rightarrow \text { median duration of treatment }=7 \text { days } \\
\text { PCT }<0.5 \mu \mathrm{g} / \mathrm{l} \text { or PCT levels decreased by at least } 80 \% \text { of their maximum value } \rightarrow \text { antibiotic therapy should be discontinued }\end{array}$ & [22] \\
\hline PCT $<0.25 \mathrm{ng} / \mathrm{ml}$ and a decrease in PCT level of $80 \%$ or more from peak level $\rightarrow$ antibiotic therapy discontinuation & [59] \\
\hline $\begin{array}{l}\text { PCT monitoring } \rightarrow \text { reduction of antibiotic therapy duration in the range of } 0-8 \text { days when compared with the standard } \\
\text { care - no impact on infection relapses }\end{array}$ & {$[19,21,42,52,53,62-68]$} \\
\hline $\begin{array}{l}\text { Patients with }>3 \text { days since CAP symptoms onset } \rightarrow \text { lower PCT } \\
\text { PCT should be used as a biomarker for antibiotic initiation only within the first } 48 \text { hours since onset of symptoms }\end{array}$ & [69] \\
\hline Viral coinfections tend to decrease PCT levels & [72] \\
\hline Severe forms of H1N1 with respiratory failure show elevated levels of PCT in the absence of proven bacterial co-infection & [74] \\
\hline $\begin{array}{l}\text { Antibiotic protocol guided by serum PCT failed to reduce in-ICU and in-hospital antibiotic exposure compared to the } \\
\text { standard antibiotic therapy in patients with severe acute exacerbations of COPD }\end{array}$ & [75] \\
\hline
\end{tabular}

CAP: community-acquired pneumonia; COPD: chronic obstructive pulmonary disease; ICU: intensive care unit.

Data on immunocompromised patients is restricted to a few studies ${ }^{82-84}$ but it has been demonstrated that PCT could potentially be a biomarker to differentiate bacterial from nonbacterial conditions in immune-depressed hosts with pulmonary complications ${ }^{82}$ (Table 3 ). In a prospective, observational study PCT appeared to have a limited specificity in critically ill immunocompromised patients and PCT levels were not significantly correlated with hospital mortality ${ }^{84}$. However, PCT serum concentrations were helpful in order to rule out bacterial infections ${ }^{84}$. Indeed, several studies in the literature demonstrate that PCT is a useful biomarker for bacterial sepsis in patients with febrile neutropaenia and in some cases PCT has a greater diagnostic ability for bacterial infections than CRP ${ }^{43,85,85}$. Importantly, time to onset of initial symptomatology has never been explored in immunocompromised patients and more studies are needed to investigate this important parameter.

\section{COST CONSIDERATIONS}

The cost-effectiveness of PCT-guided protocols has been frequently questioned in the 
TABLE 3. List of comorbid conditions that elevate procalcitonin (PCT) in the absence of bacterial infection, as well as a summary of the cost-effectiveness of the PCT-guided therapy and the causes of some challenges that may arise in PCT monitoring

\begin{tabular}{|c|c|c|}
\hline Considerations for specific populations & Cost considerations & Challenges in PCT monitoring \\
\hline $\begin{array}{l}\text { Massive stress due to: severe trauma (major burns), } \\
\text { surgery, prolonged severe cardiogenic shock, } \\
\text { resuscitated cardiac arrest }\end{array}$ & $\begin{array}{l}\text { Cost of serial PCT measurements } \\
\text { outweighed by reduction in antibiotic } \\
\text { consumption }{ }^{22}\end{array}$ & $\begin{array}{l}\text { Lack of observed benefits due to modest } \\
\text { adherence and lack of serial PCT } \\
\text { measurements }\end{array}$ \\
\hline $\begin{array}{l}\text { Malignancies (such as medullary thyroid carcinoma and } \\
\text { small cell lung cancer) and chemotherapeutic drugs } \\
\text { (such as monoclonal antibodies) }{ }^{79-81}\end{array}$ & $\begin{array}{l}\text { PCT testing } \rightarrow \text { lower hospital costs, } \\
\text { compared to no PCT testing } \\
\text { related to lower hospital and ICU } \\
\text { lengths of stay, reductions in total ICU } \\
\text { and pharmacy cost of care } \text { can,88 }^{87}\end{array}$ & $\begin{array}{l}\text { Low adherence to PCT algorithms due } \\
\text { to lack of prospective audit } \\
\text { and feedback of PCT use by a } \\
\text { pharmacist team }{ }^{94}\end{array}$ \\
\hline Treatment with 0KT3 antibodies ${ }^{79,80}$ & $\begin{array}{l}\text { PCT monitoring } \rightarrow \text { cost savings of } 9.2 \% \\
\text { per hospitalisation, related to decreased } \\
\text { antibiotic therapy duration and } \\
\text { decreased hospital length of stay } y^{89}\end{array}$ & \\
\hline \multicolumn{3}{|l|}{ Antithymocyte globulin 79,80} \\
\hline \multicolumn{3}{|l|}{ Neonates in the first three days of life ${ }^{18}$} \\
\hline \multicolumn{3}{|l|}{ Immunocompromised patients ${ }^{43,82-86}$} \\
\hline \multicolumn{3}{|l|}{$\begin{array}{l}\text { Acute or chronic conditions (pancreatitis, rhabdomyoly- } \\
\text { sis, severe renal or hepatic dysfunction) }\end{array}$} \\
\hline \multicolumn{3}{|l|}{$\begin{array}{l}\text { Autoimmune diseases (Kawasaki syndrome, Goodpasture } \\
\text { syndrome, autoimmune hepatitis, rheumatoid arthritis, } \\
\text { inflammatory bowel disease, systemic erythematosus) }\end{array}$} \\
\hline Patients with transplants ${ }^{81}$ & & \\
\hline
\end{tabular}

ICU: intensive care unit.

past $^{32}$. De Jong et al. ${ }^{22}$ conclude that the cost of serial PCT measurements is outweighed by the reduction in the consumption of antibiotics, without beneficial effects on ICU and hospital stay duration, antimicrobial-related adverse events and antimicrobial resistance.

A retrospective multivariable analysis of the Premier Healthcare Database associated PCT testing with significant lower hospital costs, compared to no PCT testing ( $\$ 30,454$ versus $\$ 33,213$, $95 \%$ CI for difference 2,159-3,321, $\mathrm{p}<0.001)^{87}$. Cost savings were related to lower hospital and ICU lengths of stay, as well as reductions in total ICU and pharmacy cost of care ${ }^{87,88}$ (Table 3). Additionally, current economic analyses suggest that PCT monitoring may lead to potential cost savings of $9.2 \%$ per hospitalisation, related to decreased duration of antibiotic therapy and decreased hospital length of stay ${ }^{89}$.

\section{CHALLENGES WHEN IMPLEMENTING PROCALCITONIN MONITORING}

Despite the large volume of evidence that support the use of PCT monitoring, when implementing PCT monitoring in the real world, many challenges arise. A retrospective cohort study in 107 hospitals across the US evaluated the outcomes associated with PCT monitoring ${ }^{90}$. In this study, no benefit was associated with the use of PCT monitoring among 20,750 critically ill patients with sepsis and PCT monitoring 
was in fact associated with increased antibiotic-days (adjusted relative risk 1.1, 95\% CI 1.15-1.18) and incidence of Clostridium difficile (adjusted OR 1.42, 95\% CI 1.09-1.85) ${ }^{90}$. Potential factors contributing to the lack of observed benefits might be the modest adherence and lack of serial PCT measurements. In fact, adherence to PCT algorithms can vary greatly among different studies, ranging from $47-97 \% 18,21-23,42,52,53,62-68,91-93$. A potential reason for low adherence to PCT algorithms includes lack of prospective audit and feedback of PCT use by a pharmacist team ${ }^{94}$. The cost savings and clinical benefits of PCT measurements can only be observed when PCT is utilised in accordance with accepted algorithms, therefore methodical education and continual assessment via a dedicated pharmacist team are of great importance ${ }^{18}$.

Moreover, in a multi-centered cohort analysis of 1656 patients in 14 hospitals in the US, Huang et al. ${ }^{95}$ reported that between the PCT-guided therapy group and the usual-care group there was no significant difference in antibiotic days (mean $=4.2$ and 4.3 days) or in the proportion of patients with adverse outcomes $(11.7 \%$ and $13.1 \%)$. This study recommends that the provision of PCT assay results did not lead to less use of antibiotics than did the usual care among patients with suspected LRTIs $^{95}$. The results of this study appear to be controversial, mainly because this study only included patients for whom initial diagnosis of LRTI had been made and there was an uncertainty regarding the need of antibiotic prescription. In other words, the study excluded patients for whom bacterial infections were diagnosed or excluded immediately. Surprisingly to this patient group that they selected, the researchers included 646 asthma exacerbation patients $(39.3 \%$ of the total patient number). Moreover, the total adherence of clinicians to all PCT guideline recommendations was only around $60 \%$. Remarkably, in the group of patients with final diagnosis of CAP the adherence of all clinicians to the protocol of the study was only $39.4 \%$. Those may be the reasons why this study contrasts with the results of previous trials of PCT-guided antibiotic prescription in suspected LRTIs (Table 3).

\section{CONCLUSIONS}

Numerous clinical studies have demonstrated that PCT serum levels tend to be higher in bacterial than viral infections and that PCTbased approaches for antibiotic prescribing can safely reduce antibiotic use ${ }^{36,63,72,96}$.

However, as a biomarker, PCT exhibits a great range of sensitivity and specificity. This is possibly due to the lack of isolation of distinct bacterial pathogens in patients with LRTIs in the relevant studies ${ }^{27,97}$. Thus, additional studies in patients with comprehensive pathogen testing are needed in order to further understand the accuracy of PCT for distinguishing between viral and bacterial infections and conclude for its diagnostic accuracy across pathogens and patient populations $s^{34,37}$.

Despite their several merits, clinicians should not rely on PCT serum levels alone to guide antibiotic treatment decisions. Nevertheless, PCT guidance has led us into a new era, where rigorous research for the discovery and implementation of more specific and sensitive novel biomarkers for infection is being 
conducted. For now, PCT allows the individualisation of antibiotic treatment and can be considered a first step towards personalised medicine ${ }^{36,42,97}$.

\section{DISCLOSURES}

Dr. Karakioulaki has nothing to disclose. Dr. Stolz reports grants from Astra-Zeneca AG, Pan Gas AG, Weimann AG, Curetis AG, Boston Scientific AG, Circassia Pharmaceuticals and Lungenliga Switzerland; and payments for lectures from Astra-Zeneca AG, Novartis AG, GlaxoSmithKline AG, Roche AG, Zambon, Pfizer, Schwabe Pharma AG and Vifor AG; all outside the submitted work.

\section{REFERENCES}

1. Stolz D, Christ-Crain M, Bingisser R et al. Antibiotic treatment of exacerbations of COPD: a randomized, controlled trial comparing procalcitonin-guidance with standard therapy. Chest. 2007;131:9-19.

2. Vijay S, Dalela G. Prevalence of LRTI in Patients Presenting with Productive Cough and Their Antibiotic Resistance Pattern. J Clin Diagn Res. 2016;10: DC09-12.

3. Biscevic-Tokic J, Tokic N, Musanovic A. Pneumonia as the most common lower respiratory tract infection. Med Arch. 2013;67:442-5.

4. Wark P. Bronchitis (acute). BMJ Clin Evid. 2015; 2015:1508

5. British Thoracic Society Standards of Care C. BTS Guidelines for the Management of Community Acquired Pneumonia in Adults. Thorax. 2001; 56 Suppl 4:IV1-64.

6. Klein Klouwenberg PM, Ong DS, Bos LD et al. Interobserver agreement of Centers for Disease Control and Prevention criteria for classifying infections in critically ill patients. Crit Care Med. 2013;41:2373-8.

7. Niederman MS, Mandell LA, Anzueto A et al. Guidelines for the management of adults with community-acquired pneumonia. Diagnosis, assessment of severity, antimicrobial therapy, and prevention. Am J Respir Crit Care Med, 2001;163:1730-54

8. Mortensen EM, Coley CM, Singer DE et al. Causes of death for patients with community-acquired pneumonia: results from the Pneumonia Patient Outcomes Research Team cohort study. Arch Intern Med. 2002;162:1059-64.

9. Salluh JIF, Souza-Dantas VC, Povoa P. The current status of biomarkers for the diagnosis of nosocomial pneumonias. Curr Opin Crit Care. 2017;23:391-7.

10. Schuetz P, Christ-Crain M, Muller B. Biomarkers to improve diagnostic and prognostic accuracy in systemic infections. Curr Opin Crit Care. 2007; 13:578-85.

11. Kibe S, Adams K, Barlow G. Diagnostic and prognostic biomarkers of sepsis in critical care. J Antimicrob Chemother. 2011;66 Suppl 2:ii33-40.

12. Hey J, Thompson-Leduc P, Kirson NY et al. Procalcitonin guidance in patients with lower respiratory tract infections: a systematic review and meta-analysis. Clin Chem Lab Med. 2018;56:1200-9.
13. Barlam TF, Soria-Saucedo R, Cabral HJ, Kazis LE. Unnecessary Antibiotics for Acute Respiratory Tract Infections: Association With Care Setting and Patient Demographics. Open Forum Infect Dis. 2016;3:ofw045.

14. Srigley JA, Brooks A, Sung $M$ et al. Inappropriate use of antibiotics and Clostridium difficile infection. Am J Infect Control. 2013;41:1116-8.

15. Evans AT, Husain S, Durairaj L et al. Azithromycin for acute bronchitis: a randomised, double-blind, controlled trial. Lancet. 2002;359:1648-54.

16. Linder JA. Antibiotic Prescribing for acute respiratory infections--success that's way off the mark: comment on "A cluster randomized trial of decision support strategies for reducing antibiotic use in acute bronchitis". JAMA Intern Med. 2013;173:273-5.

17. Tonkin-Crine SK, Tan PS, van Hecke O et al. Clinician-targeted interventions to influence antibiotic prescribing behaviour for acute respiratory infections in primary care: an overview of systematic reviews. Cochrane Database Syst Rev. 2017;9:CD012252.

18. Covington EW, Roberts MZ, Dong J. Procalcitonin Monitoring as a Guide for Antimicrobial Therapy: A Review of Current Literature. Pharmacotherapy. 2018;38: 569-81.

19. Maruna P, Nedelnikova K, Gurlich R. Physiology and genetics of procalcitonin. Physiol Res. 2000;49 Suppl 1:S57-61.

20. Briel M, Schuetz P, Mueller B et al. Procalcitonin-guided antibiotic use vs a standard approach for acute respiratory tract infections in primary care. Arch Intern Med. 2008;168:2000-7; discussion 7-8.

21. Corti C, Fally M, Fabricius-Bjerre A et al. Point-of-care procalcitonin test to reduce antibiotic exposure in patients hospitalized with acute exacerbation of COPD. Int J Chron Obstruct Pulmon Dis. 2016;11:1381-9.

22. de Jong E, van Oers JA, Beishuizen A et al. Efficacy and safety of procalcitonin guidance in reducing the duration of antibiotic treatment in critically ill patients: a randomised, controlled, open-label trial. Lancet Infect Dis. 2016;16:819-27.

23. Hochreiter M, Kohler T, Schweiger AM et al. Procalcitonin to guide duration of antibiotic therapy in intensive care patients: a randomized prospective controlled trial. Crit Care. 2009;13:R83.

24. Gilbert DN. Procalcitonin as a biomarker in respiratory tract infection. Clin Infect Dis. 2011;52 Suppl 4:S346-50.

25. Linscheid P, Seboek D, Nylen ES et al. In vitro and in vivo calcitonin I gene expression in parenchymal cells: a novel product of human adipose tissue. Endocrinology. 2003;144:5578-84.

26. Dou YH, Du JK, Liu HL, Shong XD. The role of procalcitonin in the identification of invasive fungal infection-a systemic review and meta-analysis. Diagn Microbiol Infect Dis. 2013;76:464-9.

27. Watkins EJ, Guerrini J. Procalcitonin-guided treatment of lower respiratory tract infections. JAAPA. 2018;31:50-2.

28. Schneider HG, Lam QT. Procalcitonin for the clinical laboratory: a review. Pathology. 2007;39:383-90.

29. Schuetz P, Mueller B, Trampuz A. Serum procalcitonin for discrimination of blood contamination from bloodstream infection due to coagulase-negative staphylococci. Infection. 2007;35:352-5.

30. Reinhart K, Brunkhorst FM, Bone HG et al. Prevention, diagnosis, therapy and follow-up care of sepsis: 1st revision of S-2k guidelines of the German Sepsis Society (Deutsche Sepsis-Gesellschaft e.V. (DSG)) and the German Interdisciplinary Association of Intensive Care and Emergency Medicine (Deutsche Interdisziplinare Vereinigung fur Intensiv- und Notfallmedizin (DIVI)). Ger Med Sci. 2010;8:Doc14

31. Muller B, Becker KL, Schachinger $\mathrm{H}$ et al. Calcitonin precursors are reliable markers of sepsis in a medical intensive care unit. Crit Care Med. 2000;28: 977-83.

32. Kaziani K, Sotiriou A, Dimopoulos G. Duration of pneumonia therapy and the role of biomarkers. Curr Opin Infect Dis. 2017;30:221-5.

33. Wacker C, Prkno A, Brunkhorst FM, Schlattmann P. Procalcitonin as a diagnostic marker for sepsis: a systematic review and meta-analysis. Lancet Infect Dis. 2013;13:426-35.

34. Kutz A, Briel M, Christ-Crain M et al. Prognostic value of procalcitonin in respiratory tract infections across clinical settings. Crit Care. 2015;19:74. 
35. Tokman S, Schuetz P, Bent S. Procalcitonin-guided antibiotic therapy for chronic obstructive pulmonary disease exacerbations. Expert Rev Anti Infect Ther. 2011;9:727-35.

36. Schuetz P, Muller B, Christ-Crain M et al. Procalcitonin to initiate or discontinue antibiotics in acute respiratory tract infections. Evid Based Child Health. 2013;8:1297-371.

37. Self WH, Balk RA, Grijalva CG et al. Procalcitonin as a Marker of Etiology in Adults Hospitalized With Community-Acquired Pneumonia. Clin Infect Dis. 2017;65:183-90.

38. Meier MA, Branche A, Neeser OL et al. Procalcitonin-guided antibiotic treatment in patients with positive blood cultures: A patient-level meta-analysis of randomized trials. Clin Infect Dis. 2018.

39. Schuetz P, Bolliger R, Merker M et al. Procalcitonin-guided antibiotic therapy algorithms for different types of acute respiratory infections based on previous trials. Expert Rev Anti Infect Ther. 2018;16:555-64.

40. Schuetz P, Wirz Y, Sager R et al. Procalcitonin to initiate or discontinue antibiotics in acute respiratory tract infections. Cochrane Database Syst Rev. 2017;10:CD007498.

41. Woodhead M, Blasi F, Ewig S et al. Guidelines for the management of adult lower respiratory tract infections--full version. Clin Microbiol Infect. 2011; 17 Suppl 6:E1-59.

42. Schuetz P, Wirz Y, Sager R et al. Effect of procalcitonin-guided antibiotic treatment on mortality in acute respiratory infections: a patient level meta-analysis. Lancet. Infect Dis. 2018;18:95-107.

43. Simon L, Gauvin F, Amre DK et al. Serum procalcitonin and C-reactive protein levels as markers of bacterial infection: a systematic review and meta-analysis. Clin Infect Dis. 2004;39:206-17.

44. Frantzeskaki F, Orfanos SE. Treating nosocomial pneumonia: what's new. ERJ Open Res. 2018;4.

45. Karakioulaki M, Stolz D. Biomarkers in Pneumonia-Beyond Procalcitonin. Int J Mol Sci. 2019;20.

46. Torres A, Niederman MS, Chastre J et al. International ERS/ESICM/ESCMID/ALAT guidelines for the management of hospital-acquired pneumonia and ventilator-associated pneumonia: Guidelines for the management of hospital-acquired pneumonia (HAP)/ventilator-associated pneumonia (VAP) of the European Respiratory Society (ERS), European Society of Intensive Care Medicine (ESICM), European Society of Clinical Microbiology and Infectious Diseases (ESCMID) and Asociacion Latinoamericana del Torax (ALAT). Eur Respir J. 2017;50.

47. Tanriverdi H, Tor MM, Kart L et al. Prognostic value of serum procalcitonin and C-reactive protein levels in critically ill patients who developed ventilator-associated pneumonia. Ann Thorac Med. 2015;10:137-42.

48. Povoa P, Martin-Loeches I, Ramirez P et al. Biomarker kinetics in the prediction of VAP diagnosis: results from the BioVAP study. Ann Intensive Care 2016;6:32.

49. Seligman R, Meisner M, Lisboa TC et al. Decreases in procalcitonin and $\mathrm{C}$-reactive protein are strong predictors of survival in ventilator-associated pneumonia. Crit Care. 2006;10:R125.

50. Jensen JU, Heslet L, Jensen TH et al. Procalcitonin increase in early identification of critically ill patients at high risk of mortality. Crit Care Med. 2006;34:2596-602.

51. Hausfater P, Juillien G, Madonna-Py B et al. Serum procalcitonin measurement as diagnostic and prognostic marker in febrile adult patients presenting to the emergency department. Crit Care. 2007;11:R60.

52. Broyles MR. Impact of Procalcitonin-Guided Antibiotic Management on Antibiotic Exposure and Outcomes: Real-world Evidence. Open Forum Infect Dis. 2017;4:of 213.

53. Kristoffersen KB, Sogaard OS, Wejse C et al. Antibiotic treatment interruption of suspected lower respiratory tract infections based on a single procalcitonin measurement at hospital admission--a randomized trial. Clin Microbiol Infect. 2009;15:481-7.

54. Zhang YZ, Singh S. Antibiotic stewardship programmes in intensive care units: Why, how, and where are they leading us. World J Crit Care Med. 2015;4:13-28.
55. Albrich WC, Harbarth S. Pros and cons of using biomarkers versus clinical decisions in start and stop decisions for antibiotics in the critical care setting. Intensive Care Med. 2015;41:1739-51.

56. Brechot N, Hekimian G, Chastre J, Luyt CE. Procalcitonin to guide antibiotic therapy in the ICU. Int J Antimicrob Agents. 2015;46 Suppl 1:S19-24.

57. Bouadma L, Luyt CE, Tubach $\mathrm{F}$ et al. Use of procalcitonin to reduce patients' exposure to antibiotics in intensive care units (PRORATA trial): a multicentre randomised controlled trial. Lancet. 2010;375:463-74.

58. Sager R, Kutz A, Mueller B, Schuetz P. Procalcitonin-guided diagnosis and antibiotic stewardship revisited. BMC Med. 2017;15:15.

59. Schuetz P, Albrich W, Mueller B. Procalcitonin for diagnosis of infection and guide to antibiotic decisions: past, present and future. BMC Med. 2011; 9:107.

60. Grace E, Turner RM. Use of procalcitonin in patients with various degrees of chronic kidney disease including renal replacement therapy. Clin Infect Dis. 2014;59:1761-7.

61. Schuetz P, Briel M, Christ-Crain M et al. Procalcitonin to guide initiation and duration of antibiotic treatment in acute respiratory infections: an individual patient data meta-analysis. Clin Infect Dis. 2012;55:651-62.

62. Albrich WC, Dusemund F, Bucher B et al. Effectiveness and safety of procalcitonin-guided antibiotic therapy in lower respiratory tract infections in "real life": an international, multicenter poststudy survey (ProREAL). Arch Intern Med. 2012;172: 715-22

63. Branche AR, Walsh EE, Vargas R et al. Serum Procalcitonin Measurement and Viral Testing to Guide Antibiotic Use for Respiratory Infections in Hospitalized Adults: A Randomized Controlled Trial. J Infect Dis. 2015;212 1692-700.

64. Long W, Li LJ, Huang GZ et al. Procalcitonin guidance for reduction of antibiotic use in patients hospitalized with severe acute exacerbations of asthma: a randomized controlled study with 12-month follow-up. Crit Care. 2014;18:471.

65. Christ-Crain M, Stolz D, Bingisser R et al. Procalcitonin guidance of antibiotic therapy in community-acquired pneumonia: a randomized trial. Am J Respir Crit Care Med. 2006;174:84-93.

66. Ogasawara T, Umezawa H, Naito Y et al. Procalcitonin-guided antibiotic therapy in aspiration pneumonia and an assessment of the continuation of oral intake. Respir Investig. 2014;52:107-13.

67. Schuetz P, Christ-Crain M, Thomann R et al. Effect of procalcitonin-based guidelines vs standard guidelines on antibiotic use in lower respiratory tract infections: the ProHOSP randomized controlled trial. JAMA. 2009;302 1059-66.

68. Stolz D, Smyrnios N, Eggimann P et al. Procalcitonin for reduced antibiotic exposure in ventilator-associated pneumonia: a randomised study. Eur Respir J. 2009;34:1364-75.

69. Mendez R, Menendez R, Cilloniz C et al. Initial Inflammatory Profile in Community-acquired Pneumonia Depends on Time since Onset of Symptoms. Am J Respir Crit Care Med. 2018;198:370-8.

70. Daniels JM, Schoorl M, Snijders D et al. Procalcitonin vs C-reactive protein as predictive markers of response to antibiotic therapy in acute exacerbations of COPD. Chest. 2010;138:1108-15.

71. Falsey AR, Becker KL, Swinburne AJ et al. Utility of serum procalcitonin values in patients with acute exacerbations of chronic obstructive pulmonary disease: a cautionary note. Int J Chron Obstruct Pulmon Dis. 2012;7: 127-35.

72. Musher DM, Bebko SP, Roig IL. Serum procalcitonin level, viral polymerase chain reaction analysis, and lower respiratory tract infection. J Infect Dis. 2014;209:631-3.

73. Pfister R, Kochanek M, Leygeber $\mathrm{T}$ et al. Procalcitonin for diagnosis of bacterial pneumonia in critically ill patients during 2009 H1N1 influenza pandemic: a prospective cohort study, systematic review and individual patient data meta-analysis. Crit Care. 2014;18:R44.

74. Guervilly C, Coisel Y, Botelho-Nevers E et al. Significance of high levels of procalcitonin in patients with influenza A (H1N1) pneumonia. J Infect. 2010;61:355-8. 
75. Daubin C, Valette $X$, Thiolliere F et al. Procalcitonin algorithm to guide initial antibiotic therapy in acute exacerbations of COPD admitted to the ICU: a randomized multicenter study. Intensive Care Med. 2018;44: 428-37.

76. Schuetz P, Beishuizen A, Broyles M et al. Procalcitonin (PCT)-guided antibiotic stewardship: an international experts consensus on optimized clinical use. Clin Chem Lab Med. 2019.

77. Meisner M. Update on procalcitonin measurements. Ann Lab Med. 2014;34: 263-73.

78. Rhodes A, Evans LE, Alhazzani W et al. Surviving Sepsis Campaign: International Guidelines for Management of Sepsis and Septic Shock: 2016. Intensive Care Med. 2017;43:304-77.

79. Schuetz P, Affolter B, Hunziker S et al. Serum procalcitonin, C-reactive protein and white blood cell levels following hypothermia after cardiac arrest: a retrospective cohort study. Eur J Clin Invest. 2010;40:376-81.

80. Brodska H, Drabek T, Malickova K et al. Marked increase of procalcitonin after the administration of anti-thymocyte globulin in patients before hematopoietic stem cell transplantation does not indicate sepsis: a prospective study. Crit Care. 2009;13:R37.

81. Dornbusch HJ, Strenger V, Sovinz P et al. Non-infectious causes of elevated procalcitonin and C-reactive protein serum levels in pediatric patients with hematologic and oncologic disorders. Support Care Cancer. 2008;16: 1035-40.

82. Stolz D, Stulz A, Muller B et al. BAL neutrophils, serum procalcitonin, and C-reactive protein to predict bacterial infection in the immunocompromised host. Chest 2007;132:504-14.

83. al-Nawas B, Shah PM. Procalcitonin in patients with and without immunosuppression and sepsis. Infection. 1996;24:434-6.

84. Bele N, Darmon M, Coquet I et al. Diagnostic accuracy of procalcitonin in critically ill immunocompromised patients. BMC Infect Dis. 2011;11:224.

85. Assicot M, Gendrel D, Carsin $\mathrm{H}$ et al. High serum procalcitonin concentrations in patients with sepsis and infection. Lancet. 1993;341:515-8.

86. Meidani M, Khorvash F, Abolghasemi H, Jamali B. Procalcitonin and quantitative $\mathrm{C}$-reactive protein role in the early diagnosis of sepsis in patients with febrile neutropenia. South Asian J Cancer. 2013;2:216-9.

87. Balk RA, Kadri SS, Cao Z et al. Effect of Procalcitonin Testing on Healthcare Utilization and Costs in Critically Ill Patients in the United States. Chest. 2017;151:23-33.
88. Schuetz P, Balk R, Briel M et al. Economic evaluation of procalcitonin-guided antibiotic therapy in acute respiratory infections: a US health system perspective. Clin Chem Lab Med. 2015;53:583-92.

89. Kip MM, Kusters R, MJ IJ, Steuten LM. A PCT algorithm for discontinuation of antibiotic therapy is a cost-effective way to reduce antibiotic exposure in adult intensive care patients with sepsis. J Med Econ. 2015;18:944-53.

90. Chu DC, Mehta AB, Walkey AJ. Practice Patterns and Outcomes Associated With Procalcitonin Use in Critically Ill Patients With Sepsis. Clin Infect Dis. 2017;64:1509-15.

91. Bishop BM, Bon JJ, Trienski TL et al. Effect of introducing procalcitonin on antimicrobial therapy duration in patients with sepsis and/or pneumonia in the intensive care unit. Ann Pharmacother. 2014;48:577-83.

92. Schroeder S, Hochreiter M, Koehler T et al. Procalcitonin (PCT)-guided algorithm reduces length of antibiotic treatment in surgical intensive care patients with severe sepsis: results of a prospective randomized study. Langenbecks Arch Surg. 2009;394:221-6.

93. Shehabi Y, Sterba M, Garrett PM et al. Procalcitonin algorithm in critically ill adults with undifferentiated infection or suspected sepsis. A randomized controlled trial. Am J Respir Crit Care Med. 2014;190:1102-10.

94. Brennan MB, Osterby K, Schulz L, Lepak AJ. Impact of Low Procalcitonin Results on Antibiotic Administration in Hospitalized Patients at a Tertiary Care Center. Infect Dis Ther. 2016;5:185-91.

95. Huang DT, Yealy DM, Filbin MR et al. Procalcitonin-Guided Use of Antibiotics for Lower Respiratory Tract Infection. N Engl J Med. 2018;379: 236-49.

96. Kruger S, Ewig S, Papassotiriou J et al. Inflammatory parameters predict etiologic patterns but do not allow for individual prediction of etiology in patients with CAP: results from the German competence network CAPNETZ. Respir Res. 2009;10:65.

97. Stolz D. Procalcitonin in Severe Community-Acquired Pneumonia: Some Precision Medicine Ready for Prime Time. Chest. 2016;150:769-71.

98. Chist-Crain M, Jaccard-Stolz D, Bingisser R et al. Effect of procalcitonin-guided treatment on antibiotic use and outcome in lower respiratory tract infections: cluster-randomized, single-blinded intervention trial. Lancet. 2004;363:600-7.

99. Nobre V, Harbarth S, Graf JD, Rohner P, Pugin J. Use of procalcitonin to shorten antibiotic treatment duration in septic patients: a randomized trial. Am J Respir Crit Care Med. 2008;177:498-505. 